\title{
Fotoperiodismo: desde la fotografía a la postfotografía
}

Por Mario Valenzuela W.

La fotografía nace en el seno de una cultura burguesa alimentada con el combustible de los negocios(1). Desde su aparición, encerraba en sí misma la potencialidad para ser reproductible. Por lo menos esto es así en el proyecto fotográfico tal como la aborda Niepce en 1825, ya que para él la fotografía es vista como hija de la litografía introducida en Francia en 1814. Para Daguerre se plantea como un proyecto distinto. Prueba de ello es que el procedimiento que presenta públicamente el 3 de julio de 1839, y ratificado el 19 de agosto de ese mismo año ante la Academia de Ciencias y Letras, corresponde a un sistema de reproducción único, no reproducible, en el cual el cliché y la imagen son la misma cosa.

El Hombre, que desde la Edad Media había crecido introvertido, "irremisiblemente aprisionado en la caverna platónica"(2), con el daguerrotipo abre los ojos, descubre su medio ambiente, se extiende su mirada y rápidamente desarrolla una avidez por las imágenes. Ahora los hábitos de abstracciones verbales se detuvieron y son cambiados por una riqueza de impactos visuales: "el pensar se interrumpe por el ver". La imagen ha llegado a ser socio y rival del mundo. Se ha instalado la mirada fotográfica, una nueva mirada que cambia los términos del confinamiento en dicha caverna, al enseñarnos un nuevo código visual; las fotografías alteran y amplían nuestras nociones de que vale la pena mirar y que tenemos derecho a observar.

Con la fotografía, las características perceptivas tienden a hegemonizar sensorialmente a la vista: "el ojo es más rápido captando que la mano dibujando"(3). Desde ese momento estamos en presencia de nuevos sensorium y progresivamente hemos llegado, sin darnos cuenta, a habitar un paisaje superpoblado de imágenes, todas ellas reproducibles, comercializables, virtuales, retóricas y fragmentarias(4).

El 15 de abril de 1848, el "Illustrated London News" publica la primera imagen copiada manualmente desde una fotografía. Más tarde, el 4 de marzo de 1880, se publica por primera vez una fotografía de Stephen H. Horgan en el "New York Daily Graphic", bajo el título "A scene in Shanty Town" (barracas). A partir de este momento, paulatinamente se sumarían otros medios periodísticos en la incorporación de material fotográfico. De este modo, finalizamos el siglo XIX con diarios como el "Daily Mail", que usa regular y sistemáticamente fotografías en sus publicaciones, lo mismo que el "Daily Mirror" de Inglaterra en 1904, será seguido por el "Daily News" de Nueva York, en 1919.

La producción y distribución de fotografías se va profesionalizando. En 1904 se funda la primera agencia, "Illustrated Journals Photographic Supply Company", situación que es seguida por otras agencias, algunas de las cuales como "Magnum" agruparía a fotógrafos de relevancia internacional.

\section{La fotografia y los mass media}

La introducción de la fotografía en la prensa es un fenómeno de capital importancia. En primer lugar, como ya se dijo anteriormente, cambia la visión de las masas. El hombre común que hasta ese momento sólo podía visualizar los hechos que ocurrían a su alrededor inmediato, en su calle o en su pueblo, con la fotografía masificada se le abre una ventana al mundo(5). Los rostros de los personajes públicos, los acontecimientos que tienen lugar en el mismo país e incluso más allá de las fronteras se vuelven progresivamente familiares, se ensancha la mirada y el mundo se encoge.

La palabra escrita que habitaba los periódicos es abstracta. Fue reemplazada en buena medida por la fotografía que es reflejo concreto del mundo y que si bien es cierto que no es lo real, es por lo menos un "analogon" que se acerca a lo real, y es precisamente esa perfección analógica lo que para el sentido común definió y prefirió la fotografía en este período. 
Ahora bien, estas fotografías periodísticas se instalan en los periódicos. Estos tienen un costo de producción, el que aumenta si se incorporan fotografías, lo que en ese momento fue abordado por el "periodismo moderno" con un criterio económico de empresa que se basa en el análisis de costo-beneficio. De este modo, si queremos que aquello que vio alguna vez la mirada privilegiada del fotógrafo, muchas veces en condiciones difíciles, sea visto por millones de personas, hay que negociar a partir de las reglas impuestas por los propietarios de los medios y el mercado.

La fotografía periodística adquiere el status de mercancía, y como tal, se define al interior del discurso periodístico de masas, que entre otras cosas implica un papel modelador y al mismo tiempo movilizador por parte de la prensa, en donde se trata de dirimir y decidir lo que le conviene a la sociedad y tratar de incidir en su transformación como parte de su identidad.

Un hito en este sentido es el que se produce en 1936, momento en que aparece en Estados Unidos el primer número de una revista que llegaría a ser la más importante en su género en el mundo: LIFE. El tiraje inicial fue de 446.000 ejemplares, un año más tarde sería de un millón, hasta alcanzar la cifra de ocho millones en 1972. El mundo que se refleja en LIFE estaba lleno de luces con escasas sombras, era un pseudomundo que inspiraba falsas esperanzas a las masas.

La característica de esta revista es que estaba enteramente compuesta de fotografías y de muy buen nivel técnico y estético. El estilo que inspiró a los creadores de LIFE, corresponde a un nuevo estilo de fotoperiodismo que había sido inaugurado por revistas alemanas a principios de los años treinta y que luego sería reanudado por la revista francesa $\mathrm{Vu}(6)$. Dicho estilo permite contar historias en base exclusiva de fotografías, relegando el texto sólo a notas explicativas y pies de fotos. En Chile esta revista influencia la línea estilística de Zig Zag y Ercilla.

\section{Lenguaje de la fotografia periodistica}

La fotografía periodística: "es un mensaje, es una gramática y aun más importante, una ética de la visión"(7). Esta nueva mirada nos da la sensación que podemos atrapar el mundo entero en nuestras cabezas a través del conjunto de ese mensaje fotográfico-periodístico, que está constituido por una fuente emisora, el canal de transmisión y una fuente receptora o receptor. La fuente emisora es la redacción del periódico, el grupo de técnicos (diagramadores, separadores de colores, fotomecánicos, fotógrafos, etc.). Unos sacan la fotografía, otros la seleccionan, la componen, la tratan, le ponen título, leyenda o pie de foto y la comentan, finalmente otros realizan el tramado y separación de colores y la imprimen. El medio receptor es el público que lee el periódico. Y el canal de transmisión es el periódico mismo, concretamente, una serie de mensajes y textos concurrentes con los cuales la fotografía debe convivir. Se supone que la fotografía es el centro de atención y cuyos contornos están representados por el título, la leyenda, la compaginación y de manera más abstracta, pero no menos significativa, el nombre del diario en la cual se encuentra, ya que éste encierra una carga semántica de orden estilístico, ideológico y cultural, que puede desviar notablemente la lectura del mensaje fotográfico propiamente tal.

En el proceso de significación fotográfica siempre hay algún grado de reducción, ya sea en aspectos de proporción, perspectiva, color, como en otros referentes al "corte" de espacio y tiempo inherentes al momento mismo del encuadre y obturación. Sin embargo, pese a esto, para pasar de lo real a la fotografía, no es necesario segmentar esa realidad en unidades y erigir estas mismas en signos sustancialmente diferentes del objeto cuya lectura proponen. "Entre ese objeto y su imagen, no es necesario disponer de un relevo, es decir un código"(8). En efecto, en una fotografía, al contenido analógico en sí (escena, objeto, paisaje), se suma un mensaje suplementario, que es lo que llamamos corrientemente "estilo" de la reproducción. Se trata en este caso de un sentido secundario, cuyo significante es un cierto tratamiento de la imagen por parte del creador y cuyo significado, ya sea estético o ideológico, remite una cierta cultura de la sociedad que recibe el mensaje. 
En un primer nivel de análisis, en la fotografía aparece predominando el carácter puramente denotante, el que además aparece resaltado por la perfección y plenitud de su analogía, lo que le otorga el valor de "objetividad o verosimilitud". Pero a la luz de una revisión más acuciosa, este concepto corre el riesgo de aparecer construido sobre una base mítica, ya que hay una gran probabilidad de que el mensaje fotográfico (especialmente el periodístico) sea connotado más que denotado y por otra parte, que este tipo de fotografía no solamente es percibida o vista, sino también "leída", es decir, que es relacionada más o menos conscientemente por el público con una reserva tradicional de signos. Ahora bien, partiendo del supuesto que todo signo supone la existencia de un código, queda pendiente establecer cómo opera el código de connotación, lo que aparentemente también ha cambiado a través del tiempo.

Como definición provisoria, se puede establecer que la connotación, es decir la imposición de un sentido secundario al mensaje fotográfico propiamente tal, se elabora en los diferentes niveles de producción de la fotografía (selección, tratamiento técnico, encuadre, compaginación): es, en suma, una codificación de lo analógico fotográfico.

Respecto a los factores y códigos de recepción que condicionan el impacto de las imágenes fotográficas periodísticas, hay que destacar que una fotografía que trae noticias de crueldades no puede hacer mella en la opinión pública, a menos que halla un contexto apropiado de predisposición y actitud respecto a ésta. Aunque el acontecimiento ha llegado a significar, precisamente algo digno de fotografiarse: "aun es la ideología, en el sentido más amplio, la que determina qué constituye un acontecimiento. En definitiva, lo que determina la posibilidad de ser afectado moralmente por fotografías es la existencia de una conciencia política relevante"(9).

\section{El texto y la imagen}

Es interesante estudiar el desarrollo y cambios experimentados en los enlaces entre imagen fotográfica y texto explicativo, acerca de lo cual observó W. Benjamin: "El que mira una revista ilustrada recibe de los pies de sus imágenes unas directivas"(10). Esto fue válido en un momento histórico, pero esta situación ha tendido a cambiar.

Antes, la imagen ilustraba al texto (lo hacía más claro); hoy en día el texto hace más pesada la imagen, le impone una cultura, una moral, una imaginación; antes había una reducción del texto a la imagen, hoy, una amplificación de una a otra: la connotación ya no se vive más que como la resonancia natural de la denotación fundamental constituida por la analogía fotográfica. Nos encontramos pues ante un proceso caracterizado de naturalización de lo cultural que determina cierto grado de imposibilidad de que la palabra "refuerce" la imagen, pues en el pasaje de una estructura a otra, se elaboran fatalmente significados secundarios.

En definitiva, la mayoría de las veces, el texto no hace más que amplificar un conjunto de connotaciones que ya están incluidas en la fotografía; pero también a veces, el texto produce o inventa un significado totalmente nuevo y que de alguna manera se proyecta retroactivamente en la imagen, hasta el punto de parecer denotado.

\section{La imagen digital y nuevos escenarios periodísticos}

La introducción total y absoluta de las imágenes fotográficas en todas las áreas de la vida social y cultural, y especialmente la de los medios de comunicación de masas, implica también la noción de intertextualidad(11). De este modo, los significados de cualquier imagen fotográfica particular no existen en forma autónoma, sino que relacionadas con otros textos, visuales y no visuales. Las fotografías pertenecen a un entorno denso de imágenes producidas masivamente, a objetos simbólicos, de espectáculo y todo tipo de signos. Dentro de este entorno, la imagen fotográfica periodística gana su significado por un flujo constante de significados entre imágenes: hace referencia al cine, al cómic, a la fotografía publicitaria, al video clip, etc. Con las tecnologías digitales y los medios de comunicación masivos, las fronteras entre la fotografía periodística y otros estilos, se hacen cada vez más difusas e 
híbridas. En definitiva, los textos fotográficos periodísticos compiten con muchos otros textos y se recrean a partir de imágenes recibidas.

Desde la guerra del Golfo en 1991, nos encontramos en un escenario donde las nuevas tecnologías y sistemas de comunicación han demostrado su eficacia en la "construcción de realidades", en las cuales no está tan nítida la frontera entre virtualidad y realidad objetiva. Nos bombardean con una gran carga de información, que inevitablemente nos lleva a recordar aquella afirmación que plantea que hoy el medio más seguro para neutralizar a alguien no es el de saberlo todo sobre él (como sucede con la obsesión literaria del control policiaco(12)), sino dándole los medios para saber todo sobre todo. Las estrategias del sistema se han invertido: "ya no lo neutralizareis con la represión y el control, sino con la información y la comunicación; lo paralizareis en forma mucho más segura con el exceso de información" (J. Baudrillard).

También a partir de la Guerra del Golfo empieza a materializarse la escisión entre fotoperiodistas -los que toman las fotografías dispuestos a activar sus responsabilidades profesionales-, y los "fotógrafos funcionarios" que realizan actividades de fotoinventario, cuestionando y decidiendo qué y cuándo debe ser publicado, lo que a su vez se articula dentro de estrategias orientadas a la creación de climas adecuados a las necesidades de dominación. Estas estrategias se pueden dividir en tres fases cualitativamente diferentes: la ausencia de imágenes, la sobresaturación de éstas y la "normalidad".

Nuestra preocupación con respecto a las nuevas tecnologías y sus efectos en la fotografía, entonces, se centra en el grado de verdad de la afirmación de que las tecnologías no obtienen resultados aislados e inevitables ni tampoco surgen de la nada en una cultura; son calculadas, deseadas e inducidas(13), lo que sugiere que la imagen digital es una abstracción inexorable de lo visual, una tecnología que reubica la visión y la rompe desde el punto de vista del espectador. Sin duda el impacto de la tecnología digital en la producción, la circulación y el consumo de imágenes fotográficas no debe ser tomado demasiado a la ligera, ya que: "en la imagen electrónica se gestaría la masificación y el repliegue hacia lo privado"(14). Lo anterior presupone un proceso de "escritura" mucho más complejo en el caso de la posfotografía (o fotografía digital).Ya no se trata solamente de un proceso mecánico de registro, sino que de una interpretación discursiva que más bien está dando cuenta de los "mundos posibles" y "pulsionales" del autor; de sus realidades interiores y exteriores. Esta vez, la fotografía no necesita tener un referente. Con esto, el campo de acción de la imagen ha llegado a ser autónomo, incluso a cuestionar la existencia del "mundo real".

En el contexto del periodismo moderno, especialmente en el soporte Internet, la fotografía, de acuerdo a lo que hemos visto, adquiere un potencial inusitado: "ha tomado a su cargo muchas de las funciones que el intelectual moderno creía suyas"(15). Los intelectuales de la industria comunicacional, difunden sus opiniones con la misma certidumbre y la misma fuerza impositiva que los intelectuales clásicos, pero con la gran ventaja de poseer audiencias gigantescas y de una adecuación mimética con éstas. En los mass media, las imágenes son cada vez más importantes porque median de manera efectiva, y a menudo de forma conmovedora la realidad y lo hacen a través del mundo de la simulación y el simulacro.

Si consideramos el recorrido seguido en este artículo, a partir de esas imágenes de Daguerre sin mayor posibilidad de transformación (tamaño, formato, reencuadre, etc.), hasta llegar a estas otras imágenes digitales, en las cuales es posible todo tipo de intervención y modificación, inevitablemente nos queda claro que cuando más cerca estuvimos de esa "imagen huella" fue con los daguerrotipos. Ahora en cambio, con la irrupción de las imágenes digitales, asistimos a una profunda revolución visual, que nos ha llevado a convivir con un tipo de imágenes en las cuales se pierde la relación con el referente, más aun, imágenes que son referentes sólo de sí mismas. De este modo, la fotografía se constituye en puro discurso de significantes, que actúa con un perverso tipo de lógica interna que la lleva a integrar el mundo de las mercancías.

La fotografía finalmente ha logrado desprenderse de su dependencia de la luz. Ya no necesita de la materia prima que por 150 años necesitó, tampoco necesita ser registro de la realidad ni 
"negociar" con los dueños de los medios como se dijo anteriormente. Nosotros somos los que debemos negociar con ella y con el "mundo de las imágenes del mundo", el ciberespacio y la realidad virtual. Frente a esto, ya no podemos seguir pensando en las fotografías periodísticas como reportajes reales generados casualmente sobre cosas del "mundo real" y, reconsiderar aquella frase de 1838, que uso como argumento Daguerre para atraer inversionistas para su incipiente invento: "El daguerrotipo no es meramente un instrumento que sirve para dibujar la naturaleza le da el poder de reproducirse a sí misma...".

1 GUBERN, Roman: LA MIRADA OPULENTA: La exploración de la iconósfera contemporánea. Editorial Gustavo Gili. 1987.

2 SONTAG, Susan: SOBRE LA FOTOGRAFÍA. Ed. Edhasa, Barcelona, 1981.

3 BENJAMIN, Walter: La obra de arte en la época de su reproductibilidad técnica. Pág.19.

4 BAUDRILLARD, Jean: Videosfera y Sujeto Fractal, en VIDEOCULTURAS DE FIN DE SIGLO. Ediciones Cátedra, 1989.

5 FREUND, Giselle: LA FOTOGRAFÍA COMO DOCUMENTO SOCIAL. Editorial Gustavo Gili, 1992.

6 Fundada por Lucien Vogel en 1928.

7 BARTHES, Roland : El Mensaje fotográfico, en CUADERNOS DE COMUNICACIÓN Nº 1, 1964.

8 Idem.

9 Susan Sontag. Op. cit.

10 Walter Benjamin. Op. cit.

11 Noción incorporada por Barthes y Kristeva, que implica la construcción de textos a partir de otros textos.

12 Recuérdese obras como El Mundo feliz o Orwell 1984, etc.

13 WILLIAMS, Raymond: TELEVISIÓN, TECNOLOGÍA Y FORMAS DE CULTURA. Londres, 1974.

14 MARTÍN-BARBERO, Jesús: Nuevos modos de leer. REVISTA DE CRÍTICA CULTURAL, Stgo, 1999.

15 SARLO, Beatriz: REVISTA DE ESTUDIOS SOCIALES, N 5, Bogotá, Enero 2000. 